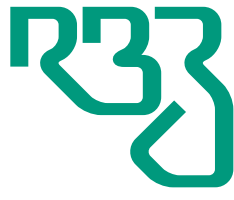

Revista Brasileira de Zootecnia

Brazilian Journal of Animal Science ISSN 1806-9290 www.rbz.org.br

\section{Impact of economic factors on formal milk collection by the dairy industry in the main producing states in Brazil: a cointegration analysis}

\author{
Jairo Vieira da Silva Filho ${ }^{1^{*}}$ (iD), Sérgio Rangel Fernandes Figueira ${ }^{1}$ \\ ${ }^{1}$ Universidade Estadual Paulista "Júlio de Mesquita Filho", Faculdade de Ciências Agrárias \\ e Veterinárias, Departamento de Economia, Administração e Educação, Jaboticabal, \\ SP, Brasil.
}

\begin{abstract}
The objective of this study was to measure the short- and long-term elasticities of the Gross Domestic Product (GDP), productivity, prices paid to producers, milk powder imports, minimum wages, and exchange ratios in milk collection between 1999 and 2016. For the measurement, the cointegration technique for data in a balanced panel was used, contemplating five states with great representativeness in the Brazilian industrial milk collection: Minas Gerais, Paraná, Rio Grande do Sul, Goiás, and São Paulo. These states corresponded to $73.3 \%$ of all formal milk collection in 2016. Results indicated that GDP, productivity, and imports impacted long-term milk collection. Productivity and GDP were the variables with the greatest long-term impact, with elasticities of 1.395 and 1.297 , respectively. Minimum wages impacted milk collection to a lesser scale, -0.802 ; and exchange ratio and imports showed lower coefficients, that is, 0.177 and -0.078 , respectively. In the short term, minimum wages was the significant variable to explain the milk collection and presented a coefficient of -0.213 . The variables with the greatest impact on formal milk collection during the period analyzed were productivity, which made the production process more efficient, and variation in the Brazilian consumer's income, represented by the GDP variable, which increased the demand for dairy products.
\end{abstract}

Keywords: economy, milk, multiple regression, price

\title{
Introduction
}

According to the Food and Agriculture Organization of the United Nations, in 2016, Brazil, with a production of 33.6 billion $\mathrm{kg}$ (milk kilogram equivalence: 1 liter $=1.030 \mathrm{~kg}$ ), was the fourth largest milk producer in the world, standing behind the USA with 96.4, India with 77.4, and China with 37.2 billion $\mathrm{kg}$ (FAOSTAT, 2018).

The milk production chain is very important socially and economically for Brazil. According to the Brazilian Confederation of Agriculture and Livestock, the Gross Value of Production (GVP) of the Brazilian dairy sector corresponded to $19.82 \%$ of the livestock GVP and $7.01 \%$ of the Brazilian GVP in 2016 (CNA, 2017). However, there is a great difference in milk production between regions, showing strong regional characteristics and great heterogeneity among the producing units (Bragagnolo et al., 2011).

Between 1999 and 2016, the production in Brazil showed a growth of 76.14\% (FAOSTAT, 2018), and according to data from the Instituto Brasileiro de Geografia e Estatística (IBGE), formal milk collection increased $107.9 \%$ during the same period (IBGE, 2018a,b). 
Considering formal milk collection in the main producing states (Minas Gerais, Paraná, Rio Grande do Sul, Goiás, and São Paulo), these were responsible for $73.3 \%$ of all milk collected in Brazil in 2016 (IBGE, 2018a,b).

In the literature, studies have identified and analyzed variables capable of impacting milk production in Brazil; however, there is a lack of recent studies that evaluate them together, in a quantitative fashion.

With this regard, Ferreira Junior and Teixeira (2004) studied the milk supply and found an elastic relation to price and workers and an inelastic relation to fuels. For Lopes et al. (2011), labor type influences the costs of milk production and change the profitability of the sector. Bragagnolo et al. (2011) identified that costs of food comprise $36.6 \%$ of all costs and workers correspond to $22.6 \%$; in addition, price elasticity was more sensitive to food. For Nascimento et al. (2012), different productive profiles suffered different impacts from the important variables to the sector, and food was the most elastic variable found. Alves et al. (2014) studied the influence from harvest and off-season periods on production. For Silva et al. (2016), different regions show different production results, and the results for such regions could be influenced by their development and structure.

The purpose of this study was to design a model based on the economic theory to measure the influence of economic variables on milk collection in Brazil. The variables used in the model were chosen by using the economic theory in models of perfect competition, in which there are many producers and consumers in the Brazilian milk sector, where prices are defined by the market, and there are no entry barriers. Therefore, in this structure, the supply is based on profit maximization (Varian, 2015), as shown in Equation 1:

$$
\text { Profit }=\text { Total revenue }(p \times q)-\text { Total costs }
$$

Total revenue will vary according to product price and quantity sold. Therefore, variations in price and quantity sold cause direct impacts on production. Variation in the income of the population has a direct influence on the sale quantity of a given product. As regards costs, minimum wages and input costs (exchange ratio) have an inverse impact on the profitability of the firm, thus discouraging production. Technological advances allow to increase the volume produced with the same amount of inputs, e.g., labor. The growth of productivity encourages companies to increase the amount produced (Pindyck and Rubinfeld, 2013).

In addition to the variables related to the microeconomic theory, milk imports were included in the model. According to Lima Filho (2017), Brazil is historically an importing country of milk derivatives, which results in a deficit in the trade balance of country dairy products. Regarding the period from 2000 and 2016, it was only in 2007 and 2008 that the country presented a surplus in these transactions, and in 2004 and 2005, there was a balance as to these aspects. Thus, it is necessary to evaluate the impact of imports on domestic production.

The hypothesis of this study is that economic variables can interfere with milk collection in the following ways: Gross Domestic Products ${ }^{1}>0$; Productivity $>0$; price $>0$; imports $<0$, exchange ratio $<0$ and minimum wages $<0$.

\section{Material and Methods}

The generated models were developed using the GRETL software (GNU, 2017). The period considered for data collection was between 1999 and 2016. Panel data ${ }^{2}$ on the formal collection of milk ${ }^{3}$ in the states of Minas Gerais, Paraná, Rio Grande do Sul, Goiás, and São Paulo, obtained from IBGE, were used

\footnotetext{
${ }^{1}$ The variation of the gross domestic product synthesizes the population's income variation.

${ }^{2}$ The model was performed in panel data, considering five of the six largest states with the highest industrial milk collection in the country. This allowed for performing the econometric analysis with a larger set of data when compared with the analysis with national data.

${ }^{3}$ The time series for milk collection shows seasonal behavior. For this reason, the model created considers this characteristic and uses it as a dummy variable.
} 
for the analysis in addition to economic variables related to the sector. However, these five states were responsible for 73.3\% of all formal milk collection in 2016 (IBGE, 2018a,b).

As to the model, considering the variables selected, data related to national GDP at market prices [chained index (1995 average = 100), with 2010 as reference] between 1999 and 2016 were collected from the Institute of Applied Economics. Nominal GDP was deflated to real GDP using IGP-M for December 2016 (IPEADATA, 2018).

Information related to productivity (L/animal/year) was obtained from the data on formal collection and cattle herding as provided by IBGE $(2018 a, b)$.

The prices paid for milk to producers were obtained from Scot Consultoria (2017). The nominal values were translated into Brazilian Reais using IGP-M for December 2016.

The import volumes of powdered and condensed milk (MCNs 0402.1010. 0402.1090; 0402.2110; 0402.2120; 0402.2130; 0402.2910; 0402.2920; 0402.9100; 0402.9900) were obtained from the Ministério da Indústria, Comércio Exterior e Serviços (MDIC, 2017).

Data on the exchange ratio (proxy variable) were analyzed, that is, how many liters of milk are needed to acquire a $40-\mathrm{kg}$ bag of animal feed (standardized value), considering prices related to the historical series of the kg of feed for the state of São Paulo, provided by the Instituto de Economia Agrícola (IEA, 2017). The feed prices considered were deflated by IGP-M for December 2016. Subsequently, to obtain the exchange rate variable, the prices paid to producers in each state were used in Equation 2:

$$
y=\frac{d x * 40}{d p},
$$

in which $y$ represents the exchange ratio value for each state; $d x$ is the feed price in São Paulo; and $d p$ is the milk price paid, considering each analyzed state. The numerical value 40 represents the feed bag weight considered.

The minimum wage values were obtained for each of the states analyzed from the Departamento Intersindical de Estatística e Estudos Socioeconômicos (DIEESE, 2017). Such values were deflated by using IGP-M for December 2016.

The cointegration model with panel data involving the states of Minas Gerais, Goiás, Rio Grande do Sul, Paraná, and São Paulo was used to measure the long- and short-term elasticities of the following variables: Gross Domestic Product, productivity, milk price, imports, minimum wages, and exchange ratios.

The $\ln$-In model was used in the long-term model to measure elasticities (see more details in Gujarati and Porter, 2012). The model used to measure the long-term elasticities can be seen in Equation 3 :

$$
\begin{aligned}
& \quad \begin{array}{l}
\ln (\text { Col. })_{i t}=\alpha+\beta_{1} \ln (G D P)_{i t}+\beta_{2} \ln (\text { Prod. })_{i t}+\beta_{3} \ln (\text { Pr. })_{i t}+\beta_{4} \ln (\text { Imp. })_{i t}+\beta_{5} \ln (\text { Rat. })_{i t}+ \\
\beta_{6} \ln (\text { Wag. })_{i t}+\beta_{7} D 2+\beta_{8} D 3+\beta_{9} D 4+u_{i}
\end{array} \\
& i=1, \ldots, 5 \\
& t=1, \ldots, 72
\end{aligned}
$$

in which Collection (Col.) is the dependent variable; National GDP (GDP), Productivity (Prod.), Imports (Imp.), Price (Pr.), Exchange Ratio (Rat.), Minimum wages (Wag.), and seasonal dummies D2, D3, and D4 are the explanatory variables; and $u_{i}$ is the stochastic error term.

In the short-term models, the elasticities were measured by using the logarithmic differences and adding the residual (Uhat) of a lag of the long-term model $\left(\mu_{\mathrm{t}-1}\right)$ (Gujarati and Porter, 2012), as shown in Equation 4:

$$
\begin{aligned}
& \Delta(\text { Col. })_{i t}=\alpha_{i}+\beta_{1} \Delta(G D P)_{i t}+\beta_{2} \Delta(\text { (Prod. })_{i t}+\beta_{3} \Delta(\text { Pr. })_{i t}+\beta_{4} \Delta(\text { (Imp. })_{i t}+\beta_{5} \Delta(\text { (Rat. })_{i t}+ \\
& \beta_{6} \Delta(\text { Wag. })_{i t}+\beta_{7} D 2+\beta_{8} D 3+\beta_{9} D 4+u_{i t-1}+\varepsilon_{i t} \\
& i=1, \ldots, 5 \\
& t=1, \ldots, 71
\end{aligned}
$$


Both in the long and in the short term, we used contemporary variables. To choose which variables should remain in the model, several models containing different variables were compared, and the model with the lowest AIC (Akaike Information Criterion) value was selected. According to Gujarati and Porter (2012), the Akaike test is usually used for model specification.

Some steps and tests are required by the cointegration model. The first condition is that all variables should be in the same order of integration, which are differences necessary to make the series stationary (Gujarati and Porter, 2012). The Kwiatkowski, Phillips, Schimidt and Shin (KPSS) test was used to determine the stationarity of the series. The null hypothesis $\left(\mathrm{H}_{0}\right)$ predicted the model to be stationary (Kwiatkowski et al., 1992).

Subsequently, the Engle-Granger test was used to evaluate the cointegration between the long- and the short-series (Engle and Granger, 1987; Gujarati and Porter, 2012). The EG test can be described in two steps:

The KPSS test - to evaluate the stationarity of the series in relation to the former (Bueno, 2011).

The Augmented Dickey-Fuller test (ADF) - for the root unit identification for the residues. The test was performed according to two models: with constant and with constant and tendency. For the choice of the best Augmented Dickey-Fuller model, including lagged values of the dependent variable, the software GRETL chose the lowest value of the Akaike Information Criterion (AIC), considering models with up to ten lags. When the root unit occurs in the analysis, it is possible to perform the KPSS test due to its grater explanatory power regarding stationarity analysis (Bueno, 2011).

The Durbin-Watson test was also used in the study to evaluate the occurrence of autocorrelation in the long- and short-term residuals. For the test, the $\mathrm{H}_{0}$ was that there was no autocorrelation (Gujarati and Porter, 2012).

\section{Results}

The KPSS test was used to evaluate the model for the stationarity of the series in the long term. All series showed integration order 1 I (1), with the series being non-stationary without the incorporation of the differences (long term) but becoming stationary with the first difference (short term) (Table 1). This is in the line with Engle-Granger's first criterion on the possibility of using cointegration models.

After using the AIC, the chosen model considered contemporary variables for national GDP, productivity, milk price paid to producers, powdered milk import, exchange ratio, minimum wages, and the dummy variables related to the quarters.

For the cointegration test (Engle-Granger test), the results of KPSS test corroborated with the first conditional (stationarity). For the second conditional, the stationarity of the Unhat1 residual was not

Table 1 - The KPSS test

\begin{tabular}{lccc}
\hline \multirow{2}{*}{ Test } & \multicolumn{3}{c}{ Critical value } \\
\cline { 2 - 4 } Constant and tendency (long term) & 0.10 & 0.05 & 0.01 \\
Constant (short term) & 0.119 & 0.146 & 0.216 \\
State & 0.347 & 0.463 & 0.739 \\
Minas Gerais & Long term & Short term \\
Paraná & 0.406 & 0.015 \\
Rio Grande do Sul & 0.374 & 0.019 \\
Goiás & 0.426 & 0.022 \\
São Paulo & 0.459 & 0.012 \\
\hline
\end{tabular}

Based on Kwiatkwoski et al. (1992). 
observed by $\mathrm{ADF}^{4}$ (Table 2). Therefore, only the model for the state of Minas Gerais showed stationary Unhat1 residual. All other models did not reject $\mathrm{H}_{0}$, thus demonstrating the existence of a unit root for the residuals. For these reason, the KPSS test was also carried out with greater power to identify stationarity in the series, on the residuals of the model (Uhat1), as performed in study by Bueno (2011). The KPSS test indicated the stationarity of the residues in all the states (Table 3). Therefore, the second condition of the Engle-Granger test for the use of the cointegration model was accepted.

The $t$ test results for the long-term model showed the significance, with a level of $1.0 \%$; the significant variables for the long term were national GDP, productivity, imports, and the second quarter (Table 4). At the significance level of $10.0 \%$, the significant variables were exchange ratio and minimum wages. Yet, for the short term, the significant variables, at the level of $1.0 \%$, were minimum wages and the second quarter. The significant variables, at the level of 5.0\%, were the second and third quarters.

Table 2 - The Engle-Granger test

\begin{tabular}{|c|c|c|c|c|c|}
\hline \multirow{2}{*}{ Table } & \multirow{2}{*}{\multicolumn{2}{|c|}{ Test }} & \multicolumn{3}{|c|}{ Critical value } \\
\hline & & & 0.01 & 0.05 & 0.10 \\
\hline Table II ${ }^{1}$ & \multicolumn{2}{|c|}{$\mathrm{ADF}$} & -3.77 & -3.17 & -2.84 \\
\hline Table III ${ }^{2}$ & \multicolumn{2}{|c|}{$\mathrm{ADF}$} & -3.73 & -3.17 & -2.91 \\
\hline State & Model & Lag & AIC & Coefficient & Result \\
\hline \multirow{2}{*}{ Minas Gerais } & $\mathrm{CC}$ & 0 & -150.330 & -4.925 & Without root unit \\
\hline & CT & 0 & -156.071 & -6.445 & Without root unit \\
\hline \multirow{2}{*}{ Paraná } & $\mathrm{CC}$ & 3 & -146.251 & -1.342 & Root unit \\
\hline & CT & 3 & -147.306 & -2.063 & Root unit \\
\hline \multirow{2}{*}{ Rio Grande do Sul } & $\mathrm{CC}$ & 8 & -116.102 & -2.450 & Root unit \\
\hline & CT & 8 & -114.180 & -2.470 & Root unit \\
\hline \multirow{2}{*}{ Goiás } & $\mathrm{CC}$ & 8 & -112.493 & -2.257 & Root unit \\
\hline & $\mathrm{CT}$ & 8 & -110.708 & -2.412 & Root unit \\
\hline \multirow{2}{*}{ São Paulo } & $\mathrm{CC}$ & 2 & -142.151 & -1.296 & Root unit \\
\hline & CT & 0 & -150.097 & -4.280 & Without root unit \\
\hline
\end{tabular}

Based on Engle and Granger (1987).

CC - constant; CT - constant and tendency.

${ }^{1}$ Test for the occurrence of zero lag.

${ }^{2}$ Test for the occurrence of 1 or more lags.

Table 3 - The KPSS test (Uhat1) for panel data

\begin{tabular}{lccccc}
\hline State & Model & Lag & Coefficient & Level of significance & Result \\
\hline \multirow{2}{*}{ Minas Gerais } & CC & 7 & 0.707 & $5.0 \%$ & Whithout root unit \\
\multirow{2}{*}{ Paraná } & CT & 0 & 0.195 & $10.0 \%$ & Whithout root unit \\
& CC & 7 & 0.686 & $5.0 \%$ & Whithout root unit \\
\multirow{2}{*}{ Rio Grande do Sul } & CT & 2 & 0.193 & $10.0 \%$ & Whithout root unit \\
& CC & 0 & 0.497 & $5.0 \%$ & Whithout root unit \\
Goiás & CT & 4 & 0.199 & $10.0 \%$ & Whithout root unit \\
& CC & 0 & 0.582 & $5.0 \%$ & Whithout root unit \\
São Paulo & CT & 4 & 0.201 & $5.0 \%$ & Whithout root unit \\
& CC & 7 & 0.681 & $5.0 \%$ & Whithout root unit \\
\hline
\end{tabular}

CC - constant; CT - constant and tendency.

${ }^{4}$ The model shows a lower Akaike value (AIC). 
Table 4 - Long- and short-term statistical results for panel data

\begin{tabular}{lccccc}
\hline \multirow{2}{*}{ Variable/Period } & \multicolumn{2}{c}{ Long term } & & \multicolumn{2}{c}{ Short term } \\
\cline { 2 - 3 } \cline { 5 - 6 } Constant & Coefficient & Confidence interval & & Coefficient & Confidence interval \\
National GDP & $-9.298^{\mathrm{a}}$ & $(-16.137 ;-2.459)$ & & $-0.026^{\mathrm{b}}$ & $(-0.049 ;-0.004)$ \\
Productivity & $1.297^{\mathrm{a}}$ & $(0.494 ; 2.099)$ & & 0.038 & $(-0.205 ; 0.282)$ \\
Price & $1.395^{\mathrm{a}}$ & $(0.876 ; 1.913)$ & & 0.370 & $(-1.399 ; 2.138)$ \\
Imports & -0.135 & $(-0.342 ; 0.072)$ & & -0.146 & $(-0.320 ; 0.028)$ \\
Exchange ratio & $-0.078^{\mathrm{a}}$ & $(-0.096 ;-0.060)$ & & -0.010 & $(-0.020 ; 0.005)$ \\
Minimum wages & $0.177^{\mathrm{c}}$ & $(-0.20 ; 0.374)$ & & 0.004 & \\
D2 & $-0.802^{\mathrm{c}}$ & $(-1.733 ; 0.130)$ & & $-0.213^{\mathrm{a}}$ & $(-0.066 ; 0.074)$ \\
D3 & $-0.096^{\mathrm{a}}$ & $(-0.130 ;-0.062)$ & & $-0.048^{\mathrm{a}}$ & $(-0.084 ;-0.013)$ \\
D4 & -0.055 & $(-0.153 ; 0.042)$ & & $0.105^{\mathrm{b}}$ & $(0.003 ; 0.206)$ \\
Uhat1 & -0.058 & $(-0.117 ; 0.000)$ & & $0.085^{\mathrm{b}}$ & $(0.013 ; 0.156)$ \\
$\mathrm{R}^{2}$ LSDV & & & $0.346^{\mathrm{a}}$ & $(0.158 ; 0.535)$ \\
$\mathrm{R}^{2}$ inside & & 0.941 & & 0.539 \\
Log-likelihood & & 0.849 & & 0.538 \\
Akaike Information Criterion & & 278.730 & & 399.260 \\
Durbin-Watson & -529.458 & & -768.521
\end{tabular}

GDP - Gross Domestic Product.

${ }^{1}$ Fixed effects.

Five cross-sectional units included: dependent variable in the long term (L_Collection); dependent variable in the short term $\left(d_{-} l_{-}\right.$Collection $)$, and robust standard errors (HAC)

a Significance at $1.0 \%$

${ }^{\mathrm{b}}$ Significance at $5.0 \%$

${ }^{\mathrm{c}}$ Significance at $10.0 \%$.

As regards elasticity, for the long term, variations of $1.0 \%$ in the growth rate of national GDP (GDP) led to positive variations in the growth rate of formal milk collection in the order of $1.297 \%$. Variations of $1.0 \%$ in the growth rate of productivity (Prod) led to positive variations in the growth rate of milk collection in the order of $1.395 \%$. Variations of $1.0 \%$ in the growth rate of Imports (Imp) led to negative variations in the growth rate of milk collection in the order of $0.078 \%$. Variations of $1.0 \%$ in the growth rate exchange ratios (Rat) led to positive variations in the growth rate of milk collection in the order of $0.177 \%$. Variations of $1.0 \%$ in the growth rate of minimum wages (Wag) led to negative variations in the growth rate of milk collection in the order of $0.802 \%$. As to the second quarter (D2), when analyzing it in relation to the constant (Const), there was a decrease in milk collection in the order of $0.096 \%$.

For the short term, variations of $1.0 \%$ in the growth rate of Wag led to negative variations in the growth rate of milk collection in the order of $-0.213 \%$. As to the second quarter (D2), when analyzing it in relation to the constant (Const), there was a decrease in milk collection in the order of $0.048 \%$, and for the third quarter, there was an increase in milk collection in the order of $0.105 \%$, while for the fourth, an increase of $0.085 \%$.

The $\mathrm{R}^{2}$ LSDV coefficient found for the long term was 0.941 , and the $\mathrm{R}^{2}$ coefficient inside was 0.849 , that is, $84.9 \%$ of the variations in the milk collection for the panel data for the long term can be explained by the variation of national GDP, productivity, powdered milk, exchange ratios, minimum wages, and seasonality.

For the short term, the $\mathrm{R}^{2} \mathrm{LSDV}$ coefficient found to the long term was 0.539 , and the $\mathrm{R}^{2}$ coefficient inside was 0.538 , that is, $53.8 \%$ of the variations in the milk collection for the panel data for the short term can be explained by the variation of minimum wages and seasonality.

According to the Durbin-Watson test, the value found for the long term was 0.829 , that is, $\mathrm{H}_{0}$ was rejected at a significance level of $1.0 \%$, thus showing a positive autocorrelation between the residuals, 
a factor that was expected due to the non-stationarity of the series. For the short term, the value found was 2.172. Therefore, the short-term model solved the problem of autocorrelation of residues.

\section{Discussion}

The generated models corroborated the economic theory, since the signs of coefficients were consistent with the initial hypothesis. Variables such as GDP, productivity, imports, exchange ratio, and minimum wages were significant in the long term. In the short term, minimum wages were relevant.

The long-term variable with the greatest impact on milk collection was productivity, with a coefficient of 1.395. This means that the increase in productivity of $1 \%$ trigged more than proportional growth in milk collection during the period, with growth of $1.395 \%$. The increase in productivity in the period was due to the investments by producers for the incorporation of new technology and management improvements.

Investment in production was the main factor considered by Marion Filho et al. (2011) to identify increase in cattle productivity, greater specialization, and concentration of milk production in the micro-regions of Rio Grande do Sul between 1990 and 2009. Camilo Neto et al. (2012), however, identified that land-related factors and higher cattle productivity were more correlated with the profitability of dairy activity than with factors related to productivity of the worker in various types of systems and sizes.

According to Vilela et al. (2017), higher productivity is mainly related to improvements in the use of production factors, such as land and labor, that is, production systems have been forced, over the years, to intensify their uses, mainly due to the high cost of variables.

The second variable with the greatest long-term impact was the national GDP variation (indicating the variation in income of Brazilians over the period), with a coefficient of 1.297, showing a change in the habits of consumers in the long term. When the income of families increases, they improve their standard of living by incorporating a greater amount of dairy products into their consumption habits, thus increasing milk collection. It is noteworthy that the decline in income generated as from 2014 also had a great impact on the consumption of dairy products and, consequently, on milk collection. The evolution of Brazilian real GDP (national GDP), deflated by IGP-M for December 2016, can be observed in Figure 1.

Hoffmann (2010) also found a significant impact of income elasticity of demand for dairy products. The income elasticity of demand of food products was measured using the family budget survey of 2008/2009. The income elasticities of dairy products mainly from the poorest extract and general average were milk powder $(0.398 ; 0.072)$, cheeses $(1.059 ; 0767)$, yogurt $(0.900 ; 0545)$, and condensed milk $(1.779 ; 0663)$.

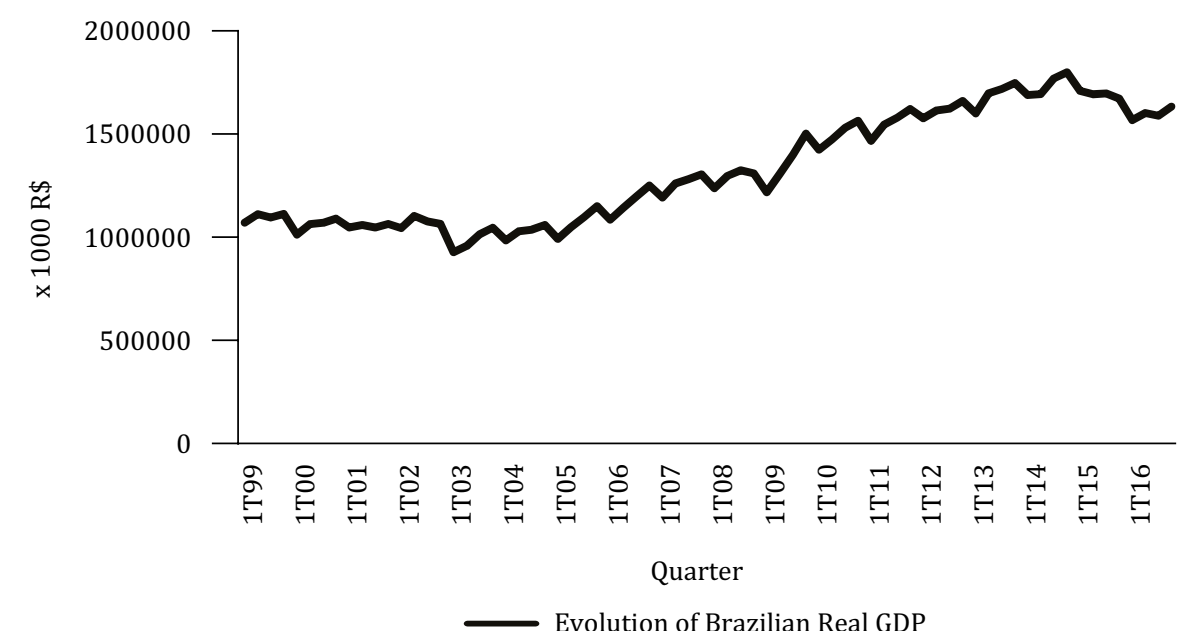

Based on IPEADATA (2018)

GDP - Gross Domestic Product.

Figure 1 - Quarterly evolution of Brazilian Real GDP (x 1000 R\$) between 1999 and 2016. 
The third variable with a long-term impact was minimum wages, with a coefficient of -0.802 . Minimum wages also impacted in the short term, but to a lesser extent, with a coefficient of -0.213 . Emphasis is given to the fact that the impact of minimum wages on production does not occur contemporaneously, since the model indicated a lag in the impact of wages in both the short and the long terms. In addition, the impact of minimum wages was greater in the long term if compared with the short term.

In a study conducted by Camilo Neto et al. (2012), 81.0\% of the properties studied in Minas Gerais in 2006 used contracted labor from nearby towns. According to Lopes et al. (2011), labor cost can range from 9.06 to $17.99 \%$. In another study, however, Santos and Lopes (2014) identified that labor in total-confinement systems may represent from 7.54 to $23.9 \%$ of the operating costs in different systems evaluated between 2008 and 2009. Still according to the authors, the difference lies in the system used and in productivity per worker, which can vary from 244 to $698 \mathrm{~L} /$ worker/day (Santos and Lopes, 2014).

Thus, it is possible to understand the importance of labor in the dairy sector in Brazil and the economic impact that it exerts on the result of the activity. According to Vilela et al. (2017), the participation of labor in the development of Brazilian agricultural production was 31.3\% in 1996 and $22.3 \%$ in 2006. On the other hand, technological evolution represented 50.6\% in 1996 and $68.1 \%$ in 2006, thus showing that mechanization and greater use of technologies is a major factor in production growth; however, it requires skilled labor, which is generally more expensive.

In the long term, the exchange ratio showed an impact on the milk collection, with a coefficient of 0.177 . The last variable diagnosed in the long term was powdered milk imports, with a coefficient of -0.078 . Therefore, although the model diagnosed the impact of imports on milk collection, the influence was less intense in relation to variables such as the productivity variation or GDP, impacting the increase in the amount of milk collected.

Brazil is historically an importer of milk and dairy products. The Brazilian import volume in 2016 was $8.2 \%$ of the total produced in the country (CONAB, 2017a,b). Due to the perishability characteristic of dairy products, its trade in the world has a predominantly regional character. For this reason and also due to trade agreements, such as Mercosur, and mainly the price of powdered milk, which is a major product commercialized in Brazil, Uruguay and Argentina are the largest exporters to the country, reaching 90.4\% of the total amount imported in 2016 (MDIC, 2017).

According to a study by Lima Filho (2017), increases in the price of powdered milk in the domestic market lead to higher importation rates for that product, mainly from Uruguay and Argentina. Data on Brazilian exports and imports of powdered milk (MCN 0402) between the 1999 and 2016 can be observed in Figure 2.

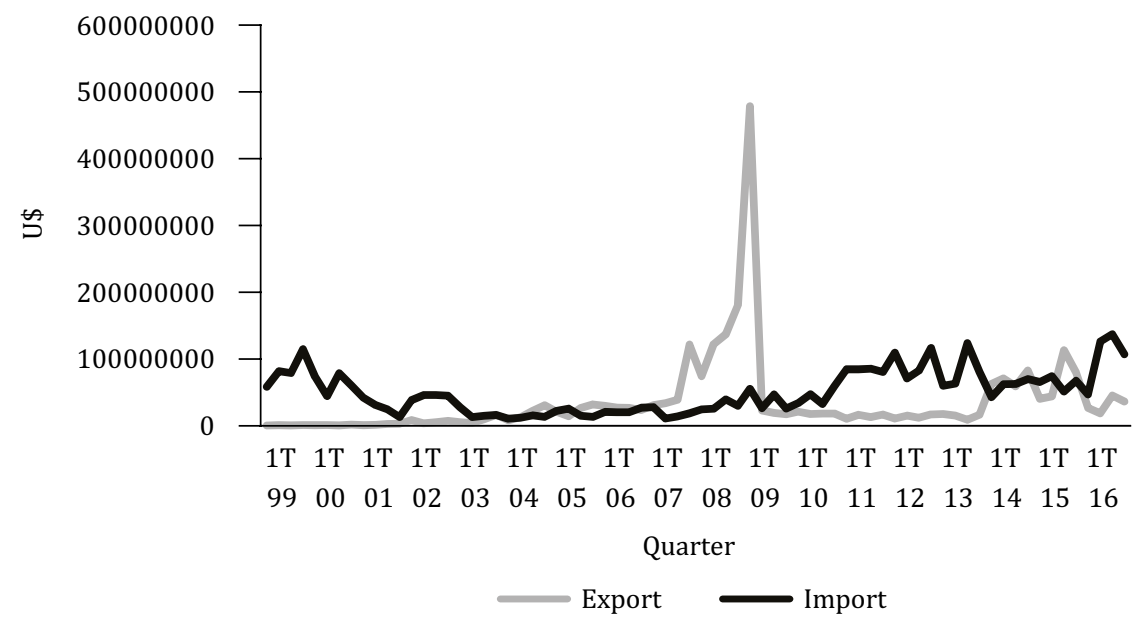

Based on MDIC (2017).

Figure 2 - Quarterly values (U\$) of the export and import from Brazil for milk powder (NCM 0402) between 1999 and 2016.

R. Bras. Zootec., 48:e20180176, 2019 
The last significant variable was seasonality, which had some influence over the long and short terms, in the second $(-0.096)$ and fourth $(-0.058)$ quarters for the long term and in second $(-0.048)$, third (0.105), and fourth $(0.085)$ quarters for the short term. This results from the fact that the grazing system is still predominant in Brazil and rainfall interferes with the supply of pastures, which is the most important bulk feed in this system.

Therefore, with the pressure for more efficient systems, both technically and economically, improvement in productivity rates (per area, per worker, and per animal) and the use of technology have been observed over the years, which represents a change in the current production systems, with the emergence of more intensive systems and animal confinement, which decrease greater variation in milk production and collection over the months.

\section{Conclusions}

The study used the cointegration technique in balanced panel data to measure the elasticities of explanatory variables: Gross Domestic Product, productivity, milk price paid to producers, milk powder imports, exchange ratios, and minimum wages in the dependent variable milk collection in the long and short terms considering the states of Minas Gerais, Paraná, Rio Grande do Sul, Goiás and São Paulo from 1999 to 2016.

Productivity and Gross Domestic Product with coefficients of 1.395 and 1.297, respectively, were the variables with the greatest impact on milk collection in the long term. Productivity gains allowed for increasing the quantity produced with fewer increments than proportional use of the inputs. Variation of GDP is used in economic models to measure the variation in the income of the population, and it has a direct impact on the demand for dairy products.

In the long-term model, it was possible to find an inverse impact, as expected according to the economic theory, of minimum wages $(-0.802)$ and imports $(-0.078)$ on milk collection. The exchange ratio had a positive impact on milk collection (0.177) and presented a reverse sign, expected by the economic theory. The minimum wages impacted at -0.213 in the short-term model.

\section{Conflict of Interest}

The authors declare no conflict of interest.

\section{Author Contributions}

Conceptualization: J.V. Silva Filho and S.R.F. Figueira. Data curation: J.V. Silva Filho and S.R.F. Figueira. Formal analysis: J.V. Silva Filho and S.R.F. Figueira. Funding acquisition: J.V. Silva Filho and S.R.F. Figueira. Investigation: J.V. Silva Filho and S.R.F. Figueira. Methodology: J.V. Silva Filho and S.R.F. Figueira. Project administration: J.V. Silva Filho and S.R.F. Figueira. Resources: J.V. Silva Filho and S.R.F. Figueira. Software: J.V. Silva Filho and S.R.F. Figueira. Supervision: S.R.F. Figueira. Validation: J.V. Silva Filho and S.R.F. Figueira. Visualization: J.V. Silva Filho and S.R.F. Figueira. Writing-original draft: J.V. Silva Filho and S.R.F. Figueira. Writing-review \& editing: J.V. Silva Filho and S.R.F. Figueira.

\section{References}

Alves, F. F.; Sousa, L. V. C. and Ervilha, G. T. 2014. Planejamento e previsão do preço do leite em Minas Gerais. Revista de Economia e Agronegócio 12:115-134.

Bragagnolo, C.; Micheleto, G. J.; Pavão, A. R.; Ferreira Filho, J. B. S. and Gomes, A. L. 2011. Elasticidades de substituição e de preços na produção de leite. Revista de Política Agrícola 20:119-130.

Bueno, R. L. S. 2011. Econometria de séries temporais. 2.ed. Cengage Learning, São Paulo.

R. Bras. Zootec., 48:e20180176, 2019 
Camilo Neto, M.; Campos, J. M. S.; Oliveira, A. S. and Gomes, S. T. 2012. Identification and quantification of benchmarks of milk production systems in Minas Gerais. Revista Brasileira de Zootecnia 41:2279-2288. https://doi.org/10.1590/ S1516-35982012001000020

CONAB - Companhia Nacional de Abastecimento. 2017a. Leite e derivados. Available at: <https://www.conab.gov.br/ info-agro/analises-do-mercado-agropecuario-e-extrativista/analises-do-mercado/historico-mensal-de-leite/item/ download/15245_55d328ef9d2f55fa9ef1855539bdc934>. Accessed on: Feb. 05, 2018.

CONAB - Companhia Nacional de Abastecimento. 2017b. Leite e derivados. Available at: <https://www.conab.gov.br/ info-agro/analises-do-mercado-agropecuario-e-extrativista/analises-do-mercado/historico-mensal-de-leite/item/ download/15242_c4bdb8edbe5fe80f0924c50537f08581>. Accessed on: Feb. 05, 2018.

CNA - Confederação da Agricultura e Pecuária do Brasil. 2017. Boletim VBP. Available at: <https://www.cnabrasil.org.br/ assets/arquivos/boletins/21-boletim-vbp_2_0.52059500\%201514916989.pdf >. Accessed on: Mar. 10, 2018.

DIEESE - Departamento Intersindical de Estatística e Estudos Socioeconômicos. 2017. Salário mínimo. Available at: <https://www.dieese.org.br/>. Accessed on: May 24, 2017.

Engle, R. F. and Granger, C. W. J. 1987. Cointegration and error correction: representation, estimation and testing. Econometrica 55:251-276.

Ferreira Junior, S. and Teixeira, E. C. 2004. Relações de produção na pecuária leiteira: um estudo de caso das respostas da produção aos preços mensais. Revista de Economia e Agronegócio 3:193-212.

FAOSTAT - Food and Agriculture Organization of the United Nations. 2018. Livestock primary. Available at: <http://www. fao.org/faostat/en/?\#data/QL>. Accessed on: Jan. 18, 2018

GNU regression, econometric and time-series library. 2017. Free Software Fundation, Boston. Available at: <http://gretl. sourceforge.net/>. Accessed on: Apr. 24, 2017.

Gujarati, D. N. and Porter, D. C. 2012. Econometria básica. 5.ed. McGraw Hill, São Paulo.

Hoffmann, R. 2010. Estimativas das elasticidades-renda de várias categorias de despesa e de consumo, especialmente alimentos no Brasil, com base na POF de 2008-2009. Revista de Economia Agrícola 57:49-62.

IBGE - Instituto Brasileiro de Geografia e Estatística Aplicada. 2018a. Pesquisa pecuária municipal. Available at: <https://www.ibge.gov.br/estatisticas-novoportal/economicas/agricultura-e-pecuaria/9107-producao-da-pecuariamunicipal.html?=\&t=series-historicas $>$. Accessed on: Mar. 24, 2018.

IBGE - Instituto Brasileiro de Geografia e Estatística Aplicada. 2018b. Pesquisa trimestral do leite. Available at: <https://www.ibge.gov.br/estatisticas-novoportal/economicas/agricultura-e-pecuaria/21121-primeiros-resultadios2leite.html?=\&t=series-historicas $>$. Accessed on: Apr. 04, 2018.

IEA - Instituto de Economia Agrícola. 2017. Preços médios mensais pagos pela Agricultura. Available at: <http://ciagri. iea.sp.gov.br/bancoiea_Teste/pagos2.aspx?cod_sis=5>. Accessed on: Mar. 07, 2017.

IPEADATA - Instituto de Pesquisa Econômica Aplicada. 2018. PIB Nacional. Available at: <http://www.ipeadata.gov.br/ Default.aspx>. Accessed on: Mar. 10, 2018.

Kwiatkowski, D.; Phillips, P. C. B.; Schmidt, P. and Shin, Y. 1992. Testing the null hypothesis of stationarity against the alternative of a unit root. Journal of Econometrics 54:159-178.

Lima Filho, R. R. 2017. Fatores econômicos determinantes da importação brasileira de leite em pó proveniente da Argentina e do Uruguai entre 2000 e 2016. Dissertação (M.Sc.). Universidade Estadual Paulista, Jaboticabal.

Lopes, M. A.; Santos, G. and Carvalho, F. M. 2011. Indicadores econômicos da atividade leiteira em regime de semiconfinamento com alta produção diária. Boletim Indústria Animal 68:113-123.

Marion Filho, P. J.; Fagundes, J. D. O. and Schumacher, G. 2011. A produção de leite no Rio Grande do Sul: produtividade, especialização e concentração (1990-2009). Revista de Economia e Agronegócio 9:233-252.

MDIC - Ministério da Indústria, Comércio Exterior e Serviços. 2017. Importação e exportação de leite e derivados, ALICEWEB2. Available at: <http://aliceweb.mdic.gov.br/>. Accessed on: Jun. 08, 2017.

Nascimento, A. C. C.; Lima, J. E.; Braga, M.; Nascimento, M. and Gomes. 2012. Eficiência técnica da atividade leiteira em Minas Gerais: uma aplicação de regressão quantílica. Revista Brasileira de Zootecnia 41:783-789.

Pindyck, R. S. and Rubinfeld, D. L. 2013. Microeconomia. 7.ed. Pearson Prentice Hall, São Paulo.

Santos, G. and Lopes, M. A. 2014. Indicadores econômicos de sistemas de produção de leite em confinamento total com alto volume de produção diária. Ciência Animal Brasileira 15:239-248.

Scot Consultoria. 2017. Série de preços do leite. Available at: <https://www.scotconsultoria.com.br/leite/?ref=mnp>. Accessed on: Feb. 15, 2017.

Silva, L. H. A.; Camara, M. R. G. and Telles, T. S. 2016. Evolução e distribuição especial da produção de leite no estado do Paraná. Revista Acta Scientiarum, Human and Social Science 36:37-47. 
Varian, H. 2015. Microeconomia: uma abordagem moderna. 9.ed. Editora Elsevier, São Paulo.

Vilela, D.; Resende, J. C.; Leite, J. B. and Alves, E. 2017. A evolução do leite no Brasil em cinco décadas. Revista de Política Agrícola 1:5-24. 